\title{
Phytoplankton carbon biomass and specific growth rates determined with the labeled chlorophyll a technique
}

\author{
D. G. Redalje* \\ Institute of Marine Resources, A-018, Scripps Institution of Oceanography, University of California, San Diego, La Jolla, \\ California 92093, USA
}

\begin{abstract}
The labeled chlorophyll a technique, based on the incorporation of $\mathrm{H}^{14} \mathrm{CO}_{3}^{-}$into chlorophyll a $(\mathrm{chl} \mathrm{a})$ gives accurate determinations of both phytoplankton carbon biomass $\left(\mathrm{C}_{\mathrm{p}}\right)$ and specific growth rate $(\mu) . C_{p}$ and $\mu$, derived from the labeled chl a method, exhibited a diel periodicity and the mean $\mu$ over $24 \mathrm{~h}$ compared well with the dilution rate for an oceanic microflagellate in $\mathrm{NH}_{4}^{+}$ limited continuous culture. The specific activity of carbon in $\mathrm{C}_{\mathrm{p}}\left(\mathrm{R}_{\mathrm{C}_{\mathrm{p}}}\right)$ and in chl a $\left(\mathrm{R}_{\mathrm{chl}}^{*}\right)$ were equal after only $2 \mathrm{~h}$ and remained the same through $24 \mathrm{~h}$. This supports the main assumption of the technique that within a useful time scale, the specific activities are equal. Values of $\mathrm{C}_{\mathrm{p}}$ and phytoplankton POC measured with a CHN analyser were the same for the microflagellate in continuous culture. Estimates of phytoplankton carbon derived from several indirect methods were either greater than (methods based on measurement of adenosine triphosphate and microscopic examination of cell counts and volumes) or less than (methods based on measurement of particulate organic carbon and chlorophyll a concentrations) values determined with the labeled chl a technique. Time course ${ }^{14} \mathrm{C}$ incubations indicate that both $\mathrm{C}_{\mathrm{p}}$ and $\mu$ exhibit diel variability through $24 \mathrm{~h}$ in the fluorescence maximum layer and overlying water column in the Southern California Bight. Phytoplankton populations in the fluorescence maximum layer grew with generation times of 2 to $3 \mathrm{~d}$, while generation times in the water column above averaged less than $1 \mathrm{~d}$.
\end{abstract}

\section{INTRODUCTION}

Accurate determination of phytoplankton carbon biomass $\left(C_{p}\right)$ and specific growth rate $(\mu)$ is essential in order to characterize the flow of organic matter through the pelagic ecosystem. The incorporation of ${ }^{14} \mathrm{C}$ by phytoplankton is a measure of the change in $\mathrm{C}_{\mathrm{p}}$ over a period of time. However, an accurate determination of $C_{p}$ is necessary before $\mu$ can be calculated, usually by the equation:

$$
\mu=\frac{1}{C_{p}} \frac{d_{p}}{d t}
$$

Various indirect methods have been used to determine $C_{p}$ with a variable degree of success. Some of these methods have been discussed elsewhere (Eppley et al., 1977; Redalje and Laws, 1981). Since particulate

\footnotetext{
- Present address: Department of Oceanography, Naval Postgraduate School, Monterey, California 93940, USA
}

organic carbon (POC) contains a variable amount of non-phytoplankton carbon (e.g. detritus, zooplankton) and the ratios of chlorophyll a ( $\mathrm{chl} \mathrm{a}$ ) or adenosine triphosphate (ATP) to $C_{p}$ are variable, estimates of $C_{p}$ based on these ratios are subject to an uncertain error.

Redalje and Laws (1981) presented a method which gives accurate determinations of both $\mathrm{C}_{\mathrm{p}}$ and $\mu$, based on the incorporation of $\mathrm{H}^{14} \mathrm{CO}_{3}^{-}$into chl a (see 'Methods' for details). Initial experiments with diatoms in batch and continuous culture in the laboratory and with natural populations in a subtropical estuary gave reasonable estimates for $\mu$ and $C_{p}$ (Redalje and Laws, 1981). However, there are several questions that must be answered before the method could be routinely applied. It is assumed in the method that by the end of the incubation the specific activity of carbon in chl a $\left(R_{\text {chl a }}^{*}\right)$, which can be measured in the field, is equal to the specific activity of $\mathrm{C}_{\mathrm{p}}\left(\mathrm{R}_{\mathrm{C}_{\mathrm{p}}}^{*}\right)$, which cannot be measured in the field (see 'Methods'; Redalje and Laws, 1981). In this study, I asked: how do $R_{C_{p}}$ and $R_{\text {chl a }}$ vary 
for an oceanic microflagellate in continuous culture and what is the minimum amount of time required before $\mathrm{R}_{\text {chl } a}$ and $\mathrm{R}_{\mathrm{C}_{\mathrm{p}}}^{*}$ become equal?

Previously used methods for measuring $\mathrm{C}_{\mathrm{p}}$ in the field all include a variable amount of contamination from non-phytoplankton carbon (Banse, 1977; Eppley et al., 1977). How do $C_{p}$ values derived from the labeled chl $a$ technique compare with those estimated by other indirect techniques?

Phytoplankton in laboratory culture frequently exhibit diel periodicity in growth rates and in photosynthetic parameters (Chisholm 1981; Harding et al., 1981). Cyclic periodicity is also important for phytoplankton in the field (Heath, 1982; Gargas et al., 1979; Maccaul and Platt, 1977). Do $C_{p}$ and $\mu$ estimated by the labeled chl a technique exhibit diel variation?

The study reported here was designed to answer the above questions by investigating the time course of ${ }^{14} \mathrm{C}$ incorporation into phytoplankton carbon and into chl $a$ using an oceanic microflagellate in continuous culture and natural populations in the waters of the Southern California Bight.

\section{MATERIALS AND METHODS}

The marine prasinophyte (clone MC-1), isolated from the North Pacific Central Gyre and tentatively identified as Mantoniella sp., was maintained in continuous culture. Cultures were established as described by Laws and Bannister (1980) with ammonium $\left(\mathrm{NH}_{4}^{+}\right)$as the nutrient limiting growth. The culture was maintained at a dilution rate $(=\mu$, mean over $24 \mathrm{~h})$ of $0.0167 \mathrm{~h}^{-1}$ at $20^{\circ} \mathrm{C}$ and illuminated with a light intensity of $290 \mu \mathrm{E} \mathrm{m}^{-2} \mathrm{~s}^{-1}$ supplied by a bank of 40 watt cool white fluorescent bulbs on a $12 \mathrm{~h}: 12 \mathrm{~h}$ light : dark (L: D) cycle.

The continuous culture growth chamber was inoculated with $100 \mu \mathrm{Ci}$ of $\mathrm{H}^{14} \mathrm{CO}_{3}^{-}$at the beginning of the photoperiod in this experiment. Samples were taken at the beginning of the experiment and after 2, 4, 6, 9, 12 and $24 \mathrm{~h}$. Each experimental sample consisted of subsamples for POC and particulate nitrogen (PN) $(15 \mathrm{ml})$, chl a $(5 \mathrm{ml})$, total ${ }^{14} \mathrm{C}$ incorporated (triplicate, $5 \mathrm{ml}$ ) and for the isolation of pure chl a $(150 \mathrm{ml})$. POC and PN samples were filtered onto precombusted Whatman glass fiber filters $\left(\mathrm{GF} / \mathrm{C}\right.$, at $450{ }^{\circ} \mathrm{C}$ for $\left.24 \mathrm{~h}\right)$ and analysed with a Hewlett-Packard model 185B CHN analyser according to the recommendations of Sharp (1974). Chl a samples were filtered onto GF/C filters and measured with a Turner Model 111 fluorometer (Holm-Hansen et al., 1965). Total particulate ${ }^{14} \mathrm{C}$ activity samples were filtered onto GF/C filters, treated as recommended by Lean and Burnison (1979) to eliminate residual $\mathrm{H}^{14} \mathrm{CO}_{3}^{-}$, and activities measured with a
Beckman LS 100 C Liquid scintillation counter (LSC) using Betaphase (Westchem) liquid scintillation cocktail. LSC efficiencies were determined using internal standard $\left({ }^{14} \mathrm{C}\right.$-toluene, New England Nuclear) additions and the external standard ratio method. Samples for the isolation of pure chl $a$ and for the determination of $\mathrm{R}_{\mathrm{chl}{ }^{\prime}} \mathrm{C}_{\mathrm{p}}$ and $\mu$ were treated as described by Redalje and Laws (1981). $C_{p}$ and $\mu$ at the end of the incubation are calculated using Eq. 2 and 3 respectively, where $\mathrm{A}^{*}$ is the total ${ }^{14} \mathrm{C}$ incorporated by the phytoplankton $\left(\mathrm{dpm} \mathrm{l}^{-1}\right), \mathrm{t}$ is the length of incubation, and $\mathrm{P} \cdot \mathrm{t}$ is the total amount of carbon produced during the incubation.

$$
\begin{gathered}
C_{p}=\frac{A^{*}}{R_{c h l a}} \\
\mu=-t^{-1} \ln \left(1-\frac{P \cdot t}{C_{p}}\right)
\end{gathered}
$$

It is assumed that, at time $\mathrm{t}, \mathrm{R}_{\mathrm{C}_{\mathrm{p}}}^{*}=\mathrm{R}_{\text {chl }}^{*}$.

Field experiments were carried out on 3 cruises to the Southern California Bight (SCBS-18), May, 1981; SCBS-19, September, 1981; SCBS-20, March, 1982) and 1 cruise off Baja California (SF3, July, 1981) (Fig. $1 \mathrm{a}, \mathrm{b})$. Samples were collected at sunrise in all cases. Incubations were performed at ambient surface water temperatures in on-deck incubators with neutral density screens to reduce incident irradiance to the appropriate level. For SCBS-18 samples were collected from the fluorescence maximum layer (about the $7 \%$ light depth) and from near the surface (2 to $3 \mathrm{~m}$ ) and incubated from sunrise to sunset in 41 pyrex bottles. On SF3, samples were taken from the $6 \%$ light depth and $50 \%$ light depth and incubated from about $1 \mathrm{~h}$ after sunrise to sunset in $4 \mathrm{l}$ pyrex bottles. The bottles were subsampled after 4,8 and $12 \mathrm{~h}$. On SCBS-19, $9 \mathrm{l}$ samples from the fluorescence maximum layer were incubated for $24 \mathrm{~h}$ from sunrise, with subsamples taken after 6, 12 and $24 \mathrm{~h}$. On SCBS-20, 91 samples from the $37 \%, 29 \%$ and $12 \%$ light depths and from the fluorescence maximum layer (about the $7 \%$ light depth) were incubated for $24 \mathrm{~h}$, from sunrise through the following sunrise with time course samples taken after $3,6,12$ and $24 \mathrm{~h}$.

In all field experiments, the water from 2 or more 51 Niskin bottles were combined in a 201 polyethylene carboy and distributed to the incubation bottles after pre-screening through $183 \mu \mathrm{m}$ nitex mesh. The initial water was sampled for chl a (single or duplicate $50 \mathrm{ml}$ or $100 \mathrm{ml}$ ) and POC and PN (single or duplicate 0.5, 0.75 or 1.01 ). Samples were inoculated with either 250 or $500 \mu \mathrm{Ci}$ of $\mathrm{H}^{14} \mathrm{CO}_{3}^{-}$. All subsequent samples (on each cruise) consisted of subsamples for chl a (single or 

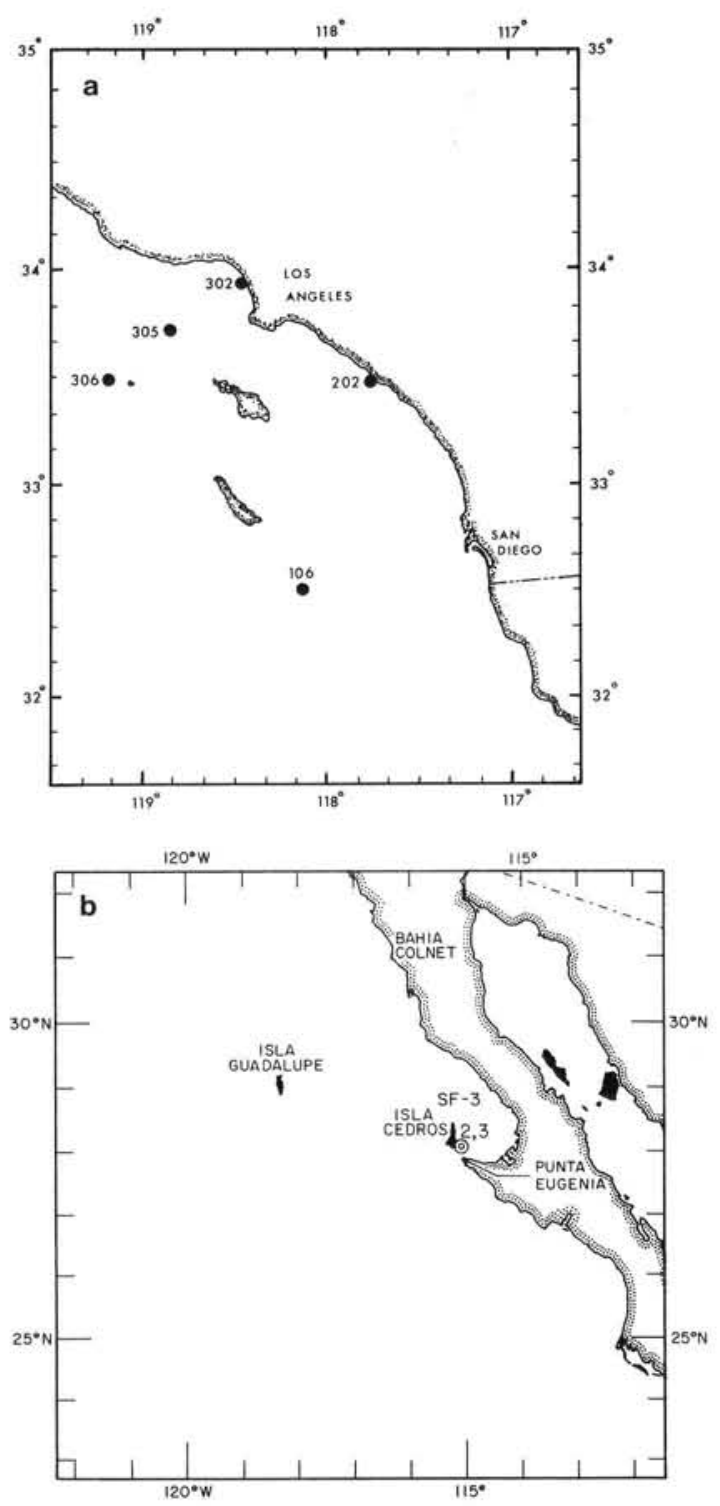

Fig. 1. Station locations. (a) Stations occupied on SCBS-18, SCBS-19 and SCBS-20; (b) stations occupied on SF3

duplicate $50 \mathrm{ml}$ or $100 \mathrm{ml}$ ), POC and PN (single or duplicate $0.5,0.75$ or 1.01 ), total incorporation of ${ }^{14} \mathrm{C}$ (triplicate, $50 \mathrm{ml}$ ) and for the isolation of pure chl a (single, 1.5 or 2.01). All samples were treated and analysed as previously described for the laboratory studies.

\section{RESULTS}

\section{Laboratory experiments}

The specific activity of the total phytoplankton carbon, $\mathrm{R}_{\mathrm{C}_{\mathrm{p}}}$, and the specific activity of the phytoplankton chlorophyll a-carbon pool, $\mathrm{R}_{\mathrm{chl}}^{*}$, varied with time of incubation in a similar manner (Fig. 2) for Mantoniella

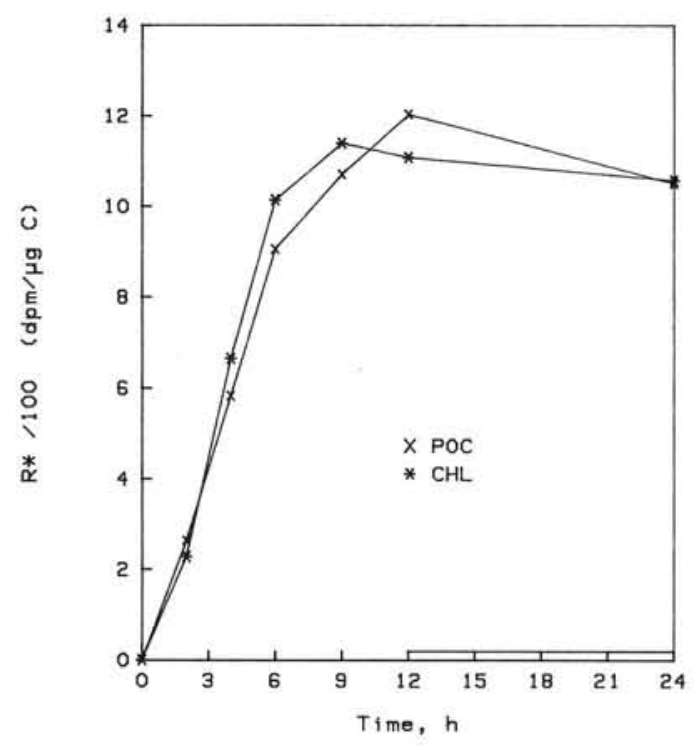

Fig. 2. Mantoniella sp. Variation in $\mathrm{R}_{\mathrm{C}_{\mathrm{p}}}\left(\mathrm{dpm} \mathrm{l}^{-1}\right)$ and $\mathrm{R}_{\mathrm{chl}}$ a (dpm $1^{-1}$ ) with time (h) for $\mathrm{NH}_{4}^{+}$-limited continuous culture under $12 \mathrm{~h}: 12 \mathrm{~h}$ light: dark photocycle

sp. A least squares (Model II, geometric mean) linear regression of $R_{C_{p}}^{*}$ vs. $R_{c h l}^{*}$ a (Eq. 4) is significant $\left(r^{2}=0.953, p<0.001\right)$; the slope is not significantly different from 1.0 and the intercept is not significantly different from $0(\mathrm{p}>0.05)$.

$$
\mathrm{R}_{\text {chl } a}^{*}=17.4+1.01\left(\mathrm{R}_{\dot{\mathrm{p}}_{\mathrm{p}}}^{*}\right)
$$

The significant relationship between $R_{\text {chl a }}$ and $R_{\dot{C}_{p}}$ (Fig. 2; Eq. 4) indicates that $R_{\text {chl a }}$ and $R_{C_{p}}$ were the

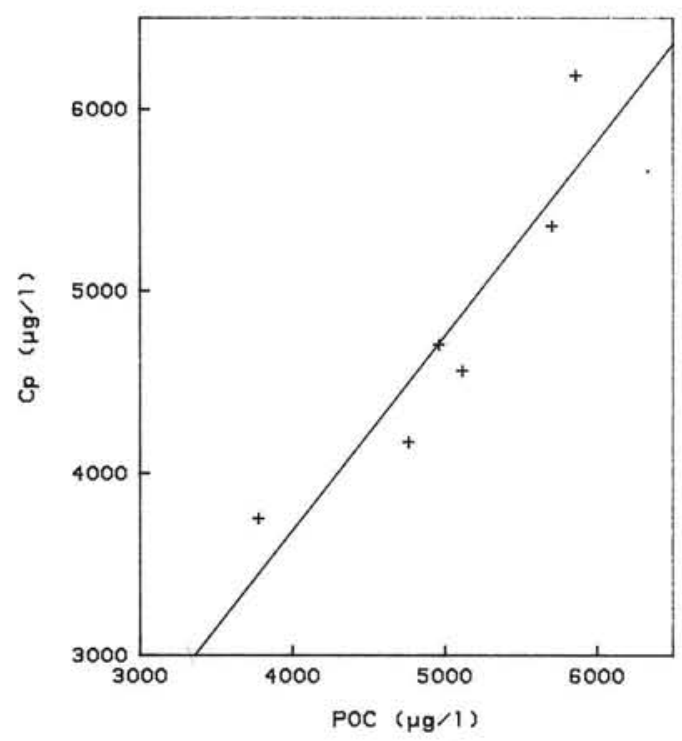

Fig. 3. Mantoniella sp. Comparison of $\mathrm{C}_{\mathrm{p}}\left(\mu \mathrm{g} \mathrm{Cl}^{-1}\right)$ derived from labeled chl a method and phytoplankton POC $\left(\mu \mathrm{g} \mathrm{Cl}^{-1}\right)$ measured with $\mathrm{CHN}$ analyzer. Least squares (Model II, geometric mean) linear regression: $\mathrm{C}_{\mathrm{p}}=-595+1.07$ (POC), $\mathrm{r}^{2}=.85$ is significant. Slope is not significantly different from 1 and intercept is not significantly different from $0(p>0.05)$ 
same after only $2 \mathrm{~h}$ under these experimental conditions (e.g. moderately low $\mu, \mathrm{NH}_{4}^{+}$-limited continuous culture).

The calculated value of $C_{p}$ at each sample time was highly correlated $\left(\mathrm{r}^{2}=.846\right)$ to the phytoplankton POC, as measured by CHN analysis (Fig. 3). The least squares (Model II, geometric mean) linear regression (Eq. 5) is significant (p $<0.01$ ); the slope of the regression line is not significantly different from 1.0 and the intercept is not significantly different from 0 ( $p>0.05)$.

$$
\mathrm{C}_{\mathrm{p}}=-595+1.07 \text { (POC), } \mu \mathrm{g} \mathrm{Cl} \mathrm{l}^{-1}
$$

$\mathrm{C}_{\mathrm{p}}$ averaged $95.1 \pm 2.7 \%$ of the phytoplankton POC.

One can calculate $\mu$ for each time interval sampled during the course of the experiment using Eq. 3 (Fig. 4). In this case, $t$ is the interval between 2 sample time points, $\mathrm{P} \cdot \mathrm{t}$ is the ${ }^{14} \mathrm{C}$ production over this time interval and $\mathrm{C}_{\mathrm{p}}$ is the phytoplankton biomass at the end of the time interval. Calculated values of $\mu$ were greater over the first $6 \mathrm{~h}$ of the photoperiod than over the second $6 \mathrm{~h}$, with the maximum $\mu$ observed in the 4 to $6 \mathrm{~h}$ interval (Fig. 4). A mean $\mu$ over $24 \mathrm{~h}\left(\bar{\mu}_{24} \mathrm{~h}\right)$ can be calculated using the geometric mean value of $\mu$ over the photoperiod $\left(=0.0433 \mathrm{~h}^{-1}\right.$; dashed line in Fig. 4) and accounting for the specific dark ${ }^{14} \mathrm{C}$ loss rate and dilution. The resulting $\bar{\mu}_{24} \mathrm{~h}$ is nearly identical to the dilution rate of the continuous culture (Fig. 4).

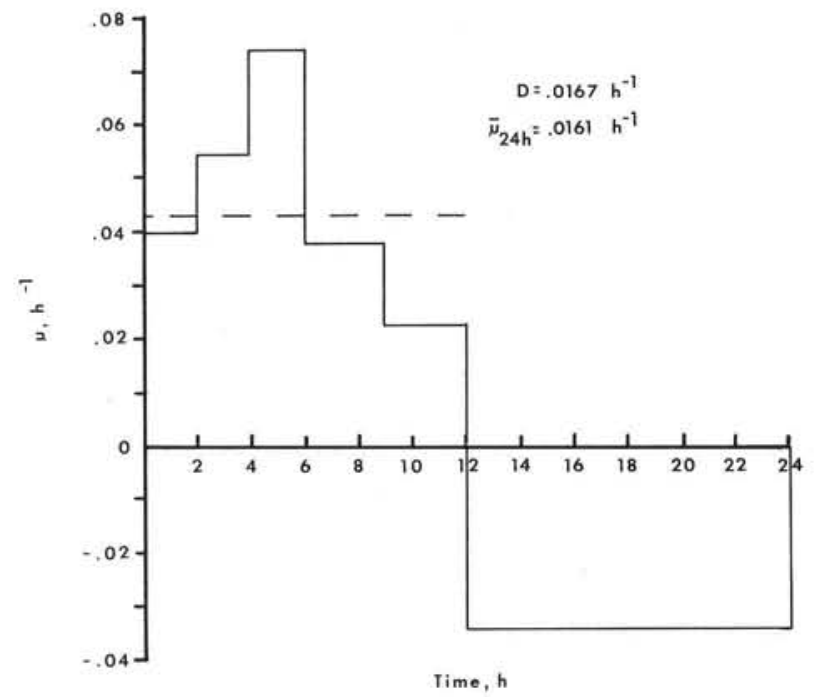

Fig. 4. Mantoniella sp. Variation in $\mu\left(\mathrm{h}^{-1}\right)$ with time for $\mathrm{NH}_{4}^{+}$ limited continuous culture under a 12 h:12 h light: dark photocycle

\section{Comparison of biomass estimates for natural populations}

The calculated $C_{p}$ (Column A, Table 1) from 3 cruises off the coast of Southern California and Baja
California (SCBS-18, 19 and SF3) have been compared to the phytoplankton $\mathrm{C}$ biomass estimates derived by the POC equation suggested by Eppley et al. (1977; phytoplankton $\left.\mathrm{C}=0.158[\mathrm{POC}]+0.0007[\mathrm{POC}]^{2}\right)$, listed in Column B (Table 1). Biomass was also estimated using microscopic determinations of phytoplankton cell volumes and C/volume ratios (Column C, Table 1; Strathmann, 1967; Beers et al., 1975) and the use of an assumed C/ATP ratio of 250 (Column D, Table 1; Holm-Hansen and Booth, 1966) for samples taken at the beginning of the incubation on SCBS-18 (values shown in Table 1 have been corrected to biomass at the end of the incubation by including the

Table 1. Estimated phytoplankton biomass, $\mu \mathrm{g} \mathrm{C} \mathrm{l}^{-1}$



Column A $-\mathrm{C}_{\mathrm{p}}$ derived from labeled chl a method.

Column B - Phytoplankton C derived from POC equation of Eppley et al. (1977).

Column C - Phytoplankton C derived from microscopic cell volume determination, C/volume ratios of initial water sample plus the ${ }^{14} \mathrm{C}$ production during the incubation.

Column D - Phytoplankton C derived from the ATP concentration in the initial water sample plus the ${ }^{14} \mathrm{C}$ production during the incubation.

Column E - Phytoplankton C derived from the concentration of chl a multiplied by a C/chl a of 25 for deep samples and of 100 for near surface samples (*).

All values represent carbon biomass within the container at the end of the incubation. 
${ }^{14} \mathrm{C}$ production over the duration of the incubation for these samples). Assumed $\mathrm{C} / \mathrm{chl}$ a ratios of 25 for fluorescence maximum layer samples and 100 for near surface samples combined with ambient chl a concentrations yielded the phytoplankton $\mathrm{C}$ values listed in Column E (Table 1). These comparisons are also shown in Fig. 5.

\section{Time Course Variation in $\mathbf{C}_{\mathbf{p}}$ and $\mu$}

Both $\mathrm{C}_{\mathrm{p}}$ and $\mu$ varied over $24 \mathrm{~h}$ for samples from the fluorescence maximum depth at 2 stations off of South-
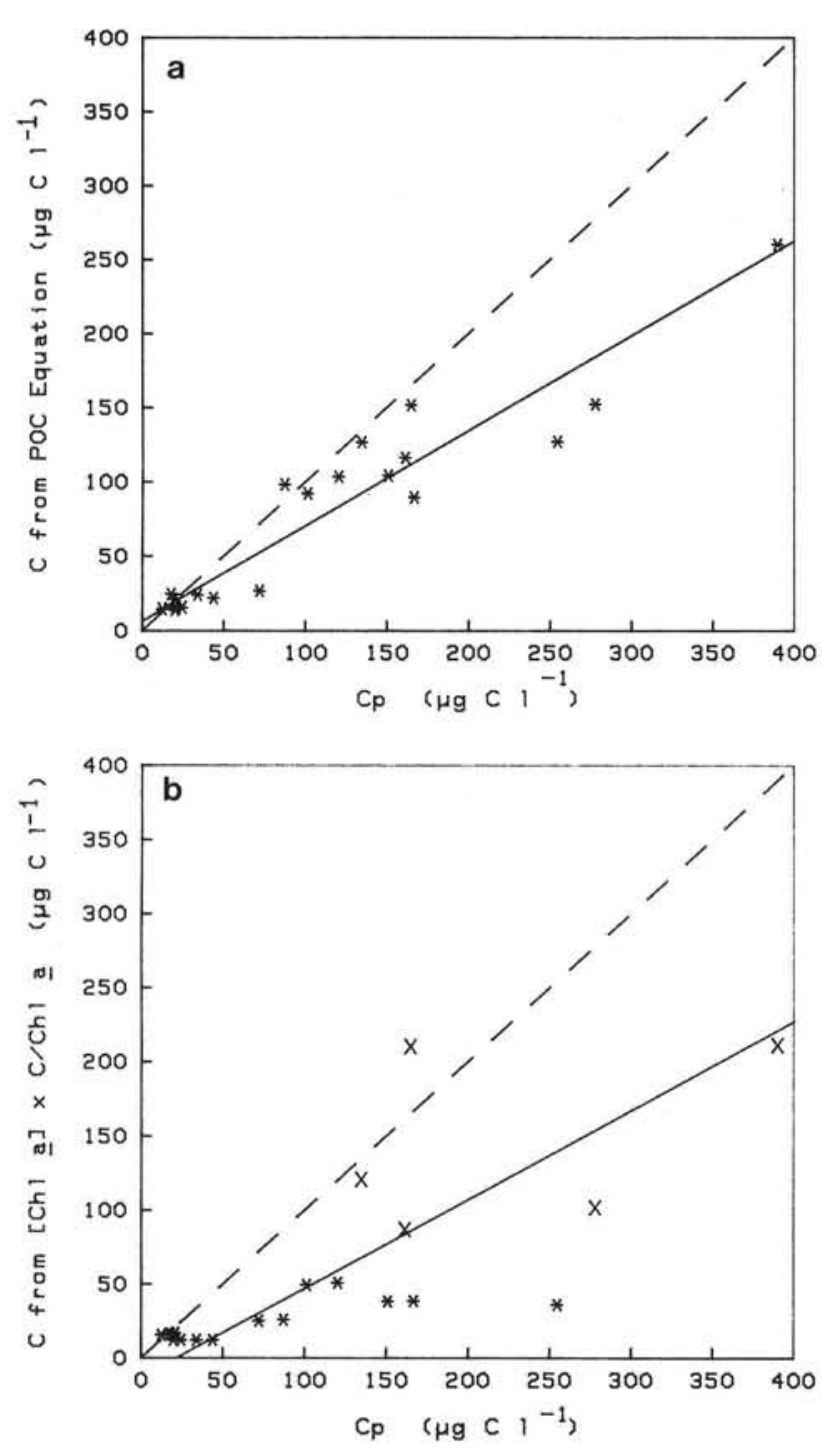

ern California in September, 1981 (Figs. 6 and 7). $C_{p}$ increased from sunrise through sunset and decreased during the night due to the combined $\mathrm{C}$ loss of respiration and excretion (Fig. 6). At both stations $\mu$ was greater during the first half of the day than during the second half (Fig. 7). One can calculate $\mu$ in 2 ways. In the first, the mean $\mu$ for the photoperiod was determined and corrected for the $24 \mathrm{~h}$ day using the specific dark $\mathrm{C}$ loss rate (rate [a] in Fig. 7). The second value of $\mu$ (rate [b] in Fig. 7) was calculated using the single 24 $\mathrm{h}$ endpoint $\mathrm{C}_{\mathrm{p}}$ and ${ }^{14} \mathrm{C}$ production (Eq. 3). Both


Fig. 5. Comparison of $\mathrm{C}_{\mathrm{p}}$ determined by labeled $\mathrm{chl}$ a method with phytoplankton carbon determined by various standard techniques for natural populations listed in Table 1. In all cases the dashed line has a slope of 1 and passes through the origin. Solid line: particular comparison. (a) $C_{p}$ vs. POC equation, $\left(C_{\text {POCeq }}\right)$ : $C_{\text {PoCeq }}=6.4+0.64 C_{p}, r^{2}=0.891$. Intercept not significantly different from $0(\mathrm{p}>0.05)$ and slope significantly different from $1.0(\mathrm{p}<0.05)$. (b) $\mathrm{C}_{\mathrm{p}} \mathrm{vs}[\mathrm{chl} a] \cdot 25 \mathrm{or}[\mathrm{chl} a] \cdot 100,\left(\mathrm{C}_{[\mathrm{chl}} \mathrm{a}\right)$ : $\mathrm{C}_{\text {[chl al }}=-12.9+0.6 \mathrm{C}_{\mathrm{p}}, \mathrm{r}^{2}=0.546$. Intercept not significantly different from $0(\mathrm{p}>0.05)$ and slope significantly different from different from 1 and intercept not significantly different from 0 (p $>0.05)$. (d) $\mathrm{C}_{\mathrm{p}}$ vS. [ATP] $:^{2} 250,\left(\mathrm{C}_{\mathrm{ATP}}\right): \mathrm{C}_{\mathrm{ATP}}=69.2+1.3 \mathrm{C}_{\mathrm{p}}$ $r^{2}=0.855$. Slope not significantly different from 1 and intercept not significantly different from $0(p>0.05)$ 


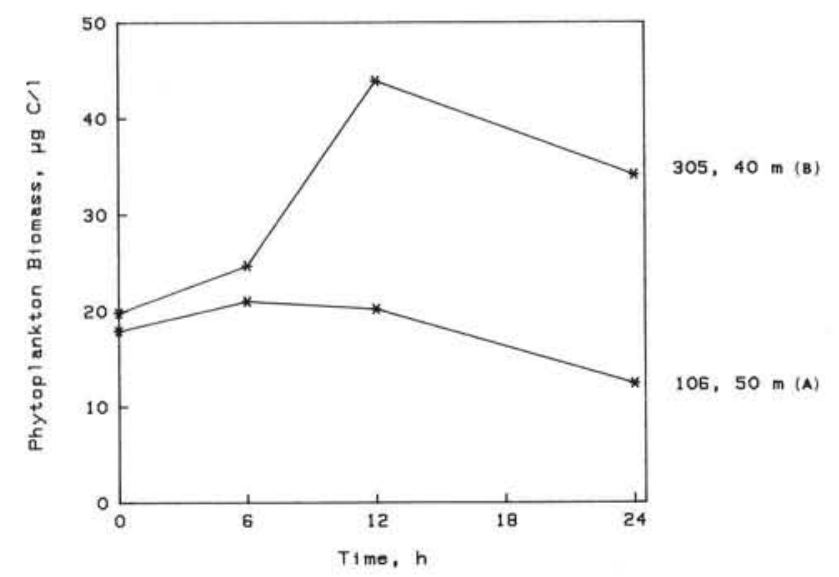

Fig. 6. Variation in $\mathrm{C}_{\mathrm{p}}$ with time for samples from fluorescence maximum layer in September, 1981 (SCBS-19)

methods yield comparable values of $\mu$ which roughly correspond to cell generation times of 2 to $3 \mathrm{~d}$.

In March, 1982 (SCBS-20), $\mathrm{C}_{\mathrm{p}}$ and $\mu$ varied both during the day and with depth at Station 305 (Figs. 1, 8 and 9). There was a general increase in $C_{p}$ through the day followed by a decrease at night at all depths (Fig. 8). As previously seen, $\mu$ was greater during the first half of the day and was markedly decreased during the second half (Fig. 9a, b, c). The variation in chl a and the POC/PN ratio within the bottles during the incubation are shown in Fig. 10a and b, respectively. The depth integrated $\mu$ for Station 305, calculated from the $24 \mathrm{~h}$ single endpoint results and extrapolated to the surface and $1 \%$ light penetration depth, was $0.024 \mathrm{~h}^{-1}$, corresponding to a cell generation time of $1.2 \mathrm{~d}$ (Fig. 11).

\section{DISCUSSION}

\section{Laboratory studies}

The results presented by Redalje and Laws (1981) strongly supported the assumption that after incubations of no more than $12 \mathrm{~h}, \mathrm{R}_{\mathrm{C}_{\mathrm{p}}}^{*}$ and $\mathrm{R}_{\mathrm{chl} \mathrm{a}}^{*}$ were equal for diatoms in both continuous and batch culture. However, at that time, the minimum length of incubation required before $\mathrm{R}_{\mathrm{C}_{\mathrm{p}}}=\mathrm{R}_{\mathrm{chl} \text { a }}$ was unknown. $\mathrm{A} 6 \mathrm{~h}$ incubation was sufficient for a rapidly growing batch culture of Thalassiosira (fluviatilis) weissflogii (Redalje and Laws, 1981). Welschmeyer and Lorenzen (manuscript in review) have presented results from time course batch culture experiments with the diatom Skeletonema costatum which indicate that under log phase growth in continuous light, $\mathrm{R}_{\dot{\mathrm{C}}_{\mathrm{p}}}^{*}=\mathrm{R}_{\mathrm{chl} \text { a }}^{*}$ after 12 h. A least squares linear regression of $R_{\text {chl a }}^{*} v s . R_{\dot{C}_{p}}^{*}$ had a slope of 1 and passed through the origin, indicating that $\mathrm{R}_{\mathrm{C}_{\mathrm{p}}}=\mathrm{R}_{\mathrm{chl} \text { a }}$ from the beginning of the incubation (Welschmeyer and Lorenzen, manuscript in review).
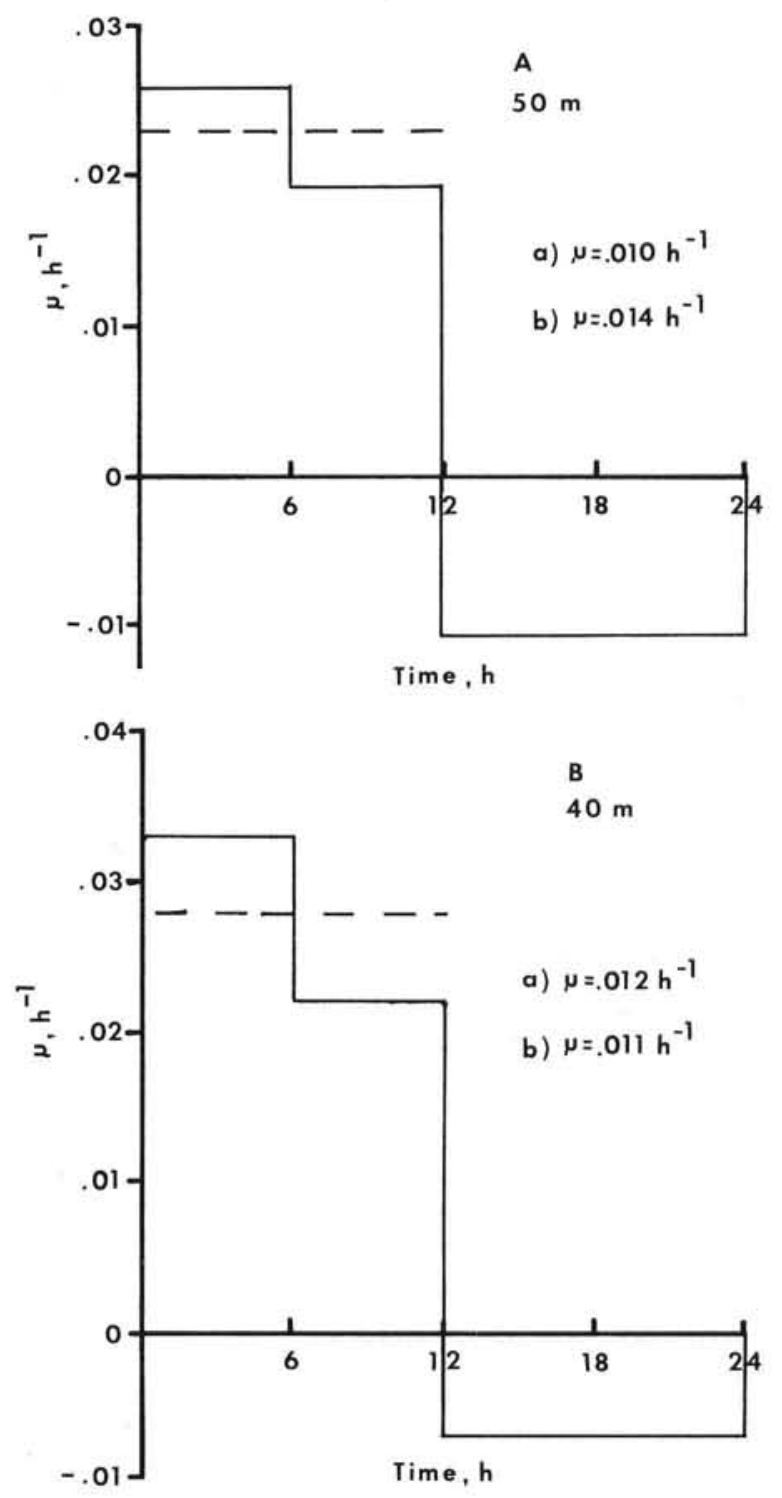

Fig. 7. Variation in $\mu\left(\mathrm{h}^{-1}\right)$ with time for samples from fluorescence maximum layer in September, 1981 (SCBS-19). (A) Station 106; (B) Station 305

This is in contrast to the results of Riper et al. (1979), for the incorporation of ${ }^{14} \mathrm{C}$ labeled $\delta$-aminolevulinic acid into chl a in $S$. costatum; they suggested that carbon growth and chl a synthesis were uncoupled allowing turnover times of chl a substantially more rapid than cell division rates. If chl a turnover was substantially greater than cellular $\mathrm{C}$ turnover, then $\mathrm{R}_{\mathrm{chl}}{ }_{\mathrm{a}}$ could be the same as $\mathrm{R}_{\dot{\mathrm{C}}_{\mathrm{p}}}$ only if the chl a precursor pool had the same specific activity as cellular $\mathrm{C}$ and if there existed a dynamic equilibrium between the $\mathrm{C}$ in the precursor pool and the chl $a-C$ pool. This is evidently the case when the cells are labeled with $\mathrm{H}^{14} \mathrm{CO}_{3}^{-}$, as evidenced by the results of this study and those of Welschmeyer and Lorenzen (manuscript in review). 


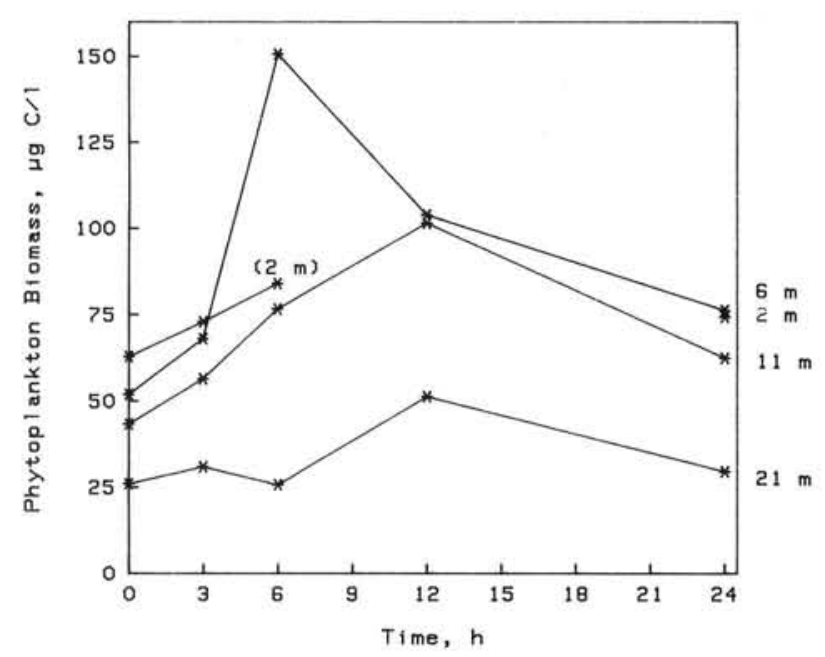

Fig. 8. Variation in $\mathrm{C}_{\mathrm{p}}$ with time for samples taken at Station 305 from 2, 6, 11 and $21 \mathrm{~m}$ in March, 1982 (SCBS-20)

\section{Comparison of phytoplankton biomass determination}

In growing laboratory cultures, lacking detritus and other non-phytoplankton carbon, one can compare any indirect estimate of the phytoplankton carbon biomass to that measured by direct analysis (e.g. with a $\mathrm{CHN}$ analyser). However, in the field, one cannot determine the actual concentration of phytoplankton carbon present by comparable chemical analysis. $\mathrm{C}_{\mathrm{p}}$, determined by the labeled chl a method has provided an accurate estimate of the phytoplankton carbon in the laboratory, and as such, was used as the standard of comparison for $\mathrm{C}$ biomass in the field. The POC equation was thought to give the most reliable estimate of phytoplankton carbon in the Southern California Bight (Eppley et al., 1977). In this study, the POC equation also gave the best agreement to $\mathrm{C}_{\mathrm{p}}$ (Table 1, Column $\mathrm{B}_{\text {; }}$ Fig. $\left.5 a, r^{2}=0.891\right)$; however, the POC estimate was
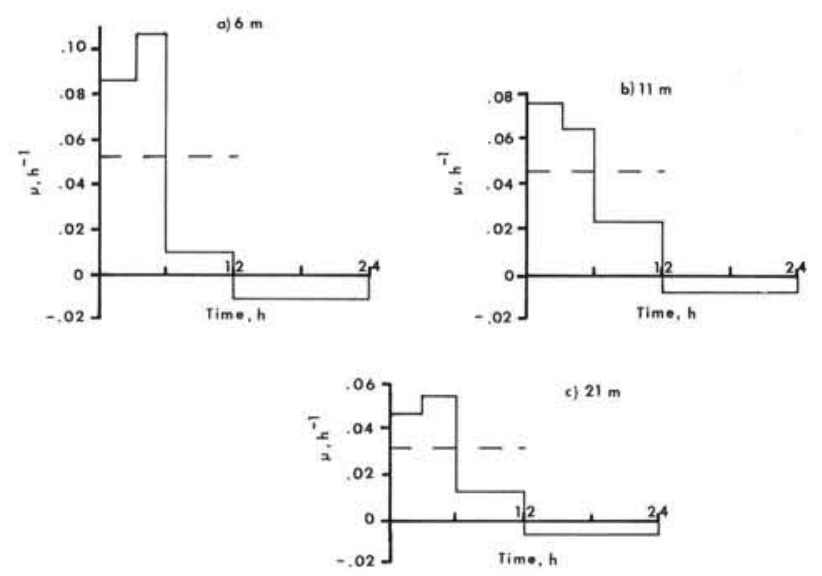

Fig. 9. Variation in $\mu\left(\mathrm{h}^{-1}\right)$ with time for samples taken at Station 305 from (a) $6 \mathrm{~m}$, (b) $11 \mathrm{~m}$, and (c) $21 \mathrm{~m}$ in March, 1982 (SCBS-20)
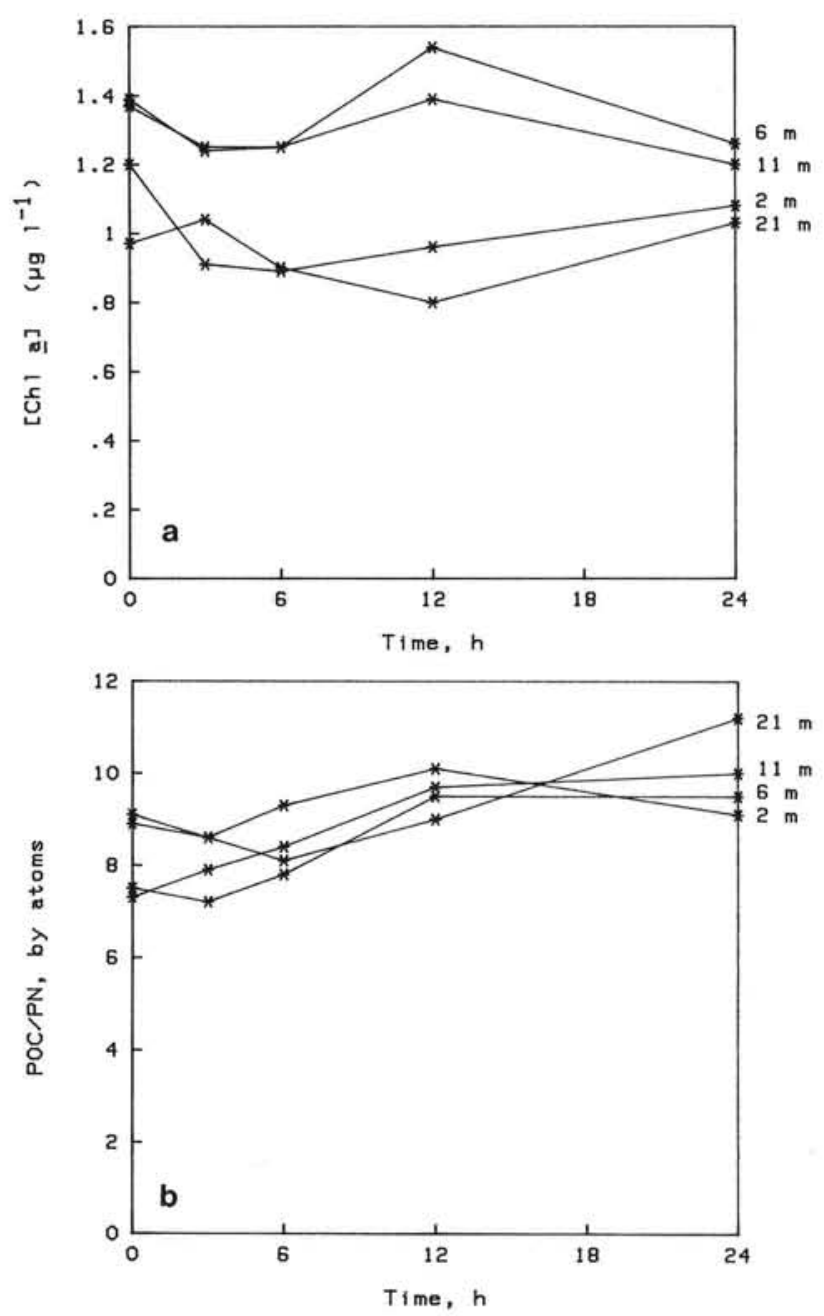

Fig. 10. Variation in chl a (a) and POC/PN (b) with time for samples taken at Station 305 from 2, 6, 11 and $21 \mathrm{~m}$ in March, 1982 (SCBS-20)

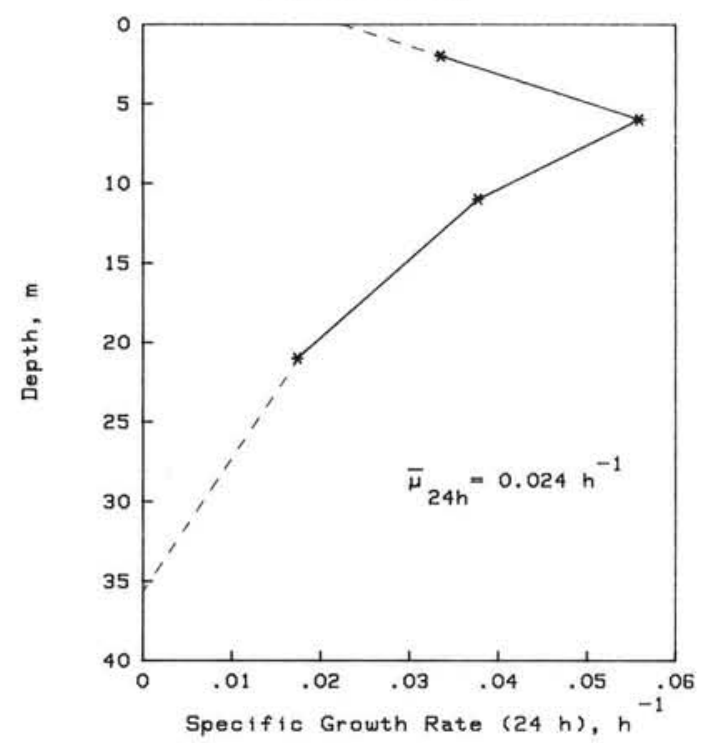

Fig. 11. Variation in $\mu$, based on single $24 \mathrm{~h}$ endpoint data for Station 305 in March, 1982 (SCBS-20) 
low by about $35 \%$ for phytoplankton C levels up to 400 $\mu \mathrm{g} \mathrm{Cl}^{-1}$. The POC method may give low values because smaller cells (e.g. microflagellates, cyanobacteria, and very small diatoms) may have been neglected in the microscopic analysis upon which the POC equation was based (F.M.H. Reid, pers. comm.).

If some knowledge is assumed about the $\mathrm{C} / \mathrm{chl} \mathrm{a}$ ratio of the phytoplankton (e.g. about 100 for near surface samples and about 25 for deeper samples (Cullen, 1982), the phytoplankton $\mathrm{C}$ biomass determined from these ratios and measured chl a concentrations could underestimate $C_{p}$ by about $40 \%$ for stations occupied off of Southern California and Baja California in this study (Fig. 5b). The scatter in the regression of phytoplankton $\mathrm{C}$ by $\mathrm{C} / \mathrm{chl}$ a ratios vs. $\mathrm{C}_{\mathrm{p}}$ also makes use of the ratios unattractive (Fig. $5 b, r^{2}=0.546$ ). A least squares linear regression (Model II, geometric mean) of POC vs. chl a for the stations represented in Fig. $5 \mathrm{~b}$ yields a slope $(=\mathrm{C} / \mathrm{chl}$ a) of 238 and is significant $(\mathrm{p}<0.01)$ although most of the variance remains unexplained $\left(\mathrm{r}^{2}=0.39\right)$. If a $\mathrm{C} / \mathrm{chl} \mathrm{a}$ of 238 is used to derive phytoplankton $\mathrm{C}_{\mathrm{r}}$ then $\mathrm{C}_{\mathrm{p}}$ is overestimated by $40 \%$.

Phytoplankton $\mathrm{C}$ based on ${ }^{14} \mathrm{C}$ incorporation over the incubation period, combined with $\mathrm{C}$ from either direct microscopic determination of cell counts and cell volumes in the initial water sample and $\mathrm{C}$ /volume relationships (Strathmann, 1967), or ATP concentrations in the initial water sample and a C/ATP ratio of 250 (Holm-Hansen and Booth, 1966) systematically overestimate $C_{p}$ (Fig. 5c, d). These comparisons are based on only 6 data points and as such, the $95 \%$ confidence limits for both the slopes and intercepts were large (Fig. 5c, d); however, the tendency for $\mathrm{C}_{\mathrm{p}}$ to be overestimated is clear. The presence of non-phytoplankton ATP and non-photosynthetic organisms may result in an unknown amount of non-phytoplankton $\mathrm{C}$ being included in each of these two methods. The POC method, originally based on the relationship between POC and phytoplankton cell counts and volumes, suffers from an unknown amount of contamination as well.

\section{Field studies}

The chlorophyll maximum layer off Southern California has been characterized as being dominated by dense aggregations of dinoflagellates with a C/chl a ratio of about 70 or by microflagellates or mixtures of flagellates and diatoms with a C/chl a ratio of about 25 (Cullen and Eppley, 1981; Cullen, 1982; Cullen et al., 1982). In these layers, the populations appear to grow with generation times of 2 to $2.5 \mathrm{~d}$, which is roughly twice the generation time of the overlying populations (Cullen and Eppley, 1981). Chlorophyll maximum populations sampled in this study grew with generation times of about 2.3 d (Fig. 7 and 9c) and were characterized by $\mathrm{C} / \mathrm{chl}$ a ratios generally between 20 and 40. Near-surface populations grew about 3 times as fast as those in the chlorophyll maximum layer, with generation times of about $0.7 \mathrm{~d}$ (Fig. 9) and had C/chl a ratios of about 50 to 70 . Although some amount of disagreement is expected from the use of different methods, we see a similarity in the generation times and $\mathrm{C}$ biomass values derived from the labeled chl a method and previous estimates for Southern California Bight populations based on $24 \mathrm{~h}{ }^{14} \mathrm{C}$ incubations and phytoplankton $\mathrm{C}$ from the POC equation of Eppley et al. (1977).

At Station 305 (SCBS-20, Fig. 1a), the mean growth rate integrated from the surface to the $1 \%$ light level was $0.024 \mathrm{~h}^{-1}$ (Fig. 11). This value is roughly twice the average integrated growth rate from previous studies at the same station and time of year derived from $24 \mathrm{~h}$ ${ }^{14} \mathrm{C}$ incubations and biomass from the POC equation ( $\mu=0.011 \pm 0.005 \mathrm{~h}^{-1}, \mathrm{n}=3$; Eppley, unpubl.)

Time-course ${ }^{14} \mathrm{C}$ incubations carried out on water taken from the fluorescence maximum layer and the overlying water column exhibit diurnal variability in both $\mu$ and $C_{p}$ in a manner similar to that observed in the continuous culture study with Mantoniella sp. (c.f. Figs. 4, 6, 7, 8 and 9). There are several consequences of this periodicity which would have a significant bearing on oceanic productivity studies. Incubations conducted for a few hours near midday could give erroneous estimates of phytoplankton production and $\mu$ if they are extrapolated to $24 \mathrm{~h}$ rates (Fig. 9). However, long-term incubations may lead to complications due to containment effects (Gieskes et al., 1979). The marked decrease in $\mu$ observed on SCBS-20 (Fig. 9a, b, c) during the second half of the day may be an artifact due to containment or nutrient depletion within the bottles. Neither chl a or $\mathrm{C}_{\mathrm{p}}$ exhibited a large decrease during this time period (Fig. 8) suggesting that mortality within the bottles was not a large factor. The POC/ PN ratio within the bottles did not exhibit a marked increase in the second half of the day as one would expect had the population become $\mathrm{N}$ depleted leading to the reduced values of $\mu$. Periodicity in $C_{p}$ and $\mu$ would have proceeded without detection had not time course samples been taken.

In conclusion, results derived from the labeled chl a technique for estimating $\mu$ and $C_{p}$ in the waters off Southern California and Baja California suggest: (1) Previous, indirect methods of estimating phytoplankton biomass tend to give either low (POC and chl a methods) or high (ATP and cell counts and volumes) values and that these values, along with measured rates of ${ }^{14} \mathrm{C}$ incorporation, lead to correspondingly high or low estimates of $\mu$. (2) Errors due to use of indirect 
biomass estimates are generally less than two-fold and are frequently better.

Acknowledgements. I would like to thank Dr. R. W. Eppley for providing laboratory space, valuable advice, assistance and support during all phases of this research. Dr. G. A. Jackson also critically reviewed the manuscript. W. Balch, S. Horrigan, J. Nelson, T. Nieman, and E. Renger provided assistance. Microscopy was performed by F. M. H. Reid. M. Ogle typed the manuscript. Financial support for research and ship time was provided by NSF grant OCE80-08308 to R. W. Eppley, NSF grant OCE79-25942 to P. M. Williams and A. F. Carlucci and by U. S. Department of Energy contract DE-AT03-82-ER60031.

\section{LITERATURE CITED}

Banse, K. (1977). Determining the carbon-to-chlorphyll ratio on natural phytoplankton. Mar. Biol. 41: 199-212

Beers, J. R., Reid, F. M. H, Stewart, G. L. (1975). Microplankton of the North Pacific Central Gyre. Population structure and abundance. Int. Revue ges. Hydrobiol. 60: 607-638

Chisholm, S. W. (1981). Temporal patterns of cell division in unicellular algae. In: Platt, T. (ed.) Physiological bases of phytoplankton ecology. Can. Bull. Fish. Aquat. Sci. 210: 150-181

Cullen, J. J. (1982). The deep chlorophyll maximum: comparing vertical profiles of chlorophyll $a$. Can. J. Fish. Aquat. Sci. 39: 791-803

Cullen, J. J., Eppley, R. W. (1981). Chlorophyll maximum layers of the Southern California Bight and possible mechanisms of their formation and maintenance. Oceanol. Acta 4: 23-32

Cullen, J. J., Reid, F. M. H., Stewart, E. (1982). Phytoplankton in the surface chlorophyll maximum off southern California in August, 1978. J. Plank. Res. 4: 665- 694

Eppley, R. W., Harrison, W. G., Chisholm, S. W., Stewart, E. (1977). Particulate organic matter in surface waters off Southern California and its relationship to phytoplankton. J. mar. Res. 35: 671-695

Gargas, E. Hare, I., Martens, P., Elder, L. (1979). Diel changes in phytoplankton photosynthetic efficiency in brackish waters. Mar. Biol. 52: 113-122

Gieskes, W. W. C., Kraay, Baars, M. A. (1979): Current ${ }^{14} \mathrm{C}$ methods for measuring primary production: gross underestimates in oceanic waters. Neth. J. Sea. Res. 13: 58-78

Harding, L. W., Meeson, B. W., Prézelin, B. B., Sweeney, B. M. (1981). Diel periodicity of photosynthesis in marine phytoplankton. Mar. Biol. 61: 95-105

Heath, M. R. (1982). Some preliminary results from a new method for studying phytoplankton physiology in the field. Mar. Biol. Lett. 3: 173-185

Holm-Hansen, O., Booth, C. R. (1966): The measurement of ATP in the ocean and its ecological significance. Limnol. Oceanogr. 11: 510-519

Holm-Hansen, O., Lorenzen, C. S., Holmes, R. W., Strickland, J. D. H. (1965). Fluorometric determination of chlorophyll. J. Cons. per. int. Explor. Mer 30: 3-15

Laws, E. A., Bannister, T. T. (1980). Nutrient- and lightlimited growth of Thalassiosira fluviatilis in continuous culture, with implications for phytoplankton growth in the ocean. Limnol. Oceanogr. 25: 457-473

Lean, D. R. S., Burnison, B. K. (1979). An evaluation of errors in the ${ }^{14} \mathrm{C}$ method of primary production measurements. Limnol. Oceanogr. 24: 917-938

Maccaul, W. A., Platt, T. (1977). Diel variations in the photosynthetic parameters of coastal marine phytoplankton. Limnol. Oceanogr. 22: 723-731

Redalje, D. G., Laws, E. A. (1981). A new method for estimating phytoplankton growth rates and carbon biomass. Mar. Biol. 62: 73-79

Riper, D. M., Owens, T. G., Falkowski, P. G. (1979). Chlorophyll turnover in Skeletonema costatum, a marine plankton diatom. Pl. Physiol., Lancaster 64: 49-54

Sharp, J. H. (1974): Improved analysis for 'particulate' organic carbon and nitrogen from seawater. Limnol. Oceanogr. 19: 984-989

Strathmann, R. R. (1967). Estimating organic carbon content of phytoplankton from cell volume or plasma volume. Limnol. Oceanogr. 12: 411-418

Welschmeyer, N., Lorenzen, C. J. (Manuscript in review). Carbon-14 labeling in phytoplankton carbon and chlorophyll a carbon. Limnol. Oceanogr. 